[J.Jpn.Soc. Starch Sci., Vol.34, No.4, p. 292 299 (1987)]

\title{
Production of Isomaltose-Hydrolyzing $\alpha$-Glucosidase by an Alkalophilic Bacillus sp.
}

\author{
Mikio Yamamoto* and Koki HoRIKosHI \\ Laboratory of Applied Bacteriology, The Institute of Physical \\ and Chemical Research (RIKEN) \\ (2-1, Hirosarea, Wako 351-01, Japan)
}

(Received July 10, 1987)

\begin{abstract}
An alkalophilic bacterium, which produces a significant amount of intracellular isomaltose. hydrolyzing $\alpha$-glucosidase, has been isolated from soil using a high alkaline $\mathrm{pH}$ medium containing $1 \% \mathrm{NaHCO}_{3}$. The bacterium can grow within the $\mathrm{pH}$ and temperature ranges of 5.010.0 and $20-55^{\circ} \mathrm{C}$, and very good growth was detected at nearly $\mathrm{pH} 9.0$ and $45^{\circ} \mathrm{C}$. The enzyme production was strongly enhanced through the induction mechanism by maltose and soluble starch. Maximal enzyme accumulation was attained during logarithmic bacterial growth in medium consisting of $1 \%$ soluble starch or maltose, $5 \%$ defatted soybean powder, $0.1 \% \mathrm{~K}_{2} \mathrm{HPO}_{4}$, $0.02 \% \mathrm{MgSO}_{4} \cdot 7 \mathrm{H}_{2} \mathrm{O}$ and $1 \% \mathrm{NaHCO}_{3}$, as a result of de novo protein synthesis. The enzyme was most active at $\mathrm{pH} 6.0-6.5$ and $45^{\circ} \mathrm{C}$.
\end{abstract}

Glucose is produced from starch and related maltooligosaccharides through the actions of glucoamylase [EC 3.2.1.3, $\alpha$-1, 4-glucan glucohydrolase] and/or $\alpha$-glucosidase [EC 3.2.1.20, $\alpha$-D-glucoside glucohydrolase]. At relatively low substrate concentrations, these enzymes hydrolyze their substrates almost completely to glucose. Industrially, starch saccharification is performed with the glucoamylase of Aspergillus niger and Rhizopus sp. at a starch concentration of about $35 \%(\mathrm{w} / \mathrm{v})$ for effective productivity. ${ }^{1)}$ At such high substrate concentrations, starch is not completely hydrolyzed to glucose by the enzymes, and small amounts of oligosaccharides such as maltose, isomaltose, panose, isopanose and isomaltotriose remained in the final reaction digests, even if debranching enzymes such as pullulanase and isoamylase are used concomitantly with the glucoamylases during the starch saccharification process. $^{2)}$ It has been reported that the condensation of $\beta$ $D$-glucose by glucoamylases is one of the major

* Present address: Research Laboratory of Nihon Shokuhin Kako Co., 30, Tajima, Fuji, Shizuoka 417, Japan. causes of incomplete hydrolysis of starch. ${ }^{3)}$ Beschkov et al. ${ }^{4)}$ and Adachi et al. ${ }^{5)}$ have reported kinetic models for the synthesis of maltose and isomaltose through the condensation of glucose by glucoamylases. In their reports, it was also mentioned that glucoamylases catalyzed the rapid hydrolysis and synthesis of maltose, and that isomaltose was hydrolyzed and synthesized more slowly, which resulted in the accumulation of higher levels of isomaltose in the reaction digests. Accordingly, novel amylolytic enzymes that hydrolyze starch completely or that decompose the undesired byproducts at higher substrate concentrations will be very important for the starch processing industry. Although there have been many reports on the characterization of various $\alpha$ glucosidases, including oligo-1,6-glucosidases [EC 3.2.1.10, oligodextrin 6- $\alpha$-D-glucanohydrolase], that hydrolyze maltose and several branched maltooligosaccharides, ${ }^{6 \sim 14)}$ little has been reported about the production and characterization of microbial enzymes capable of hydrolyzing isomaltose as a primary substrate in the presence of a high concentration of 
glucose.

A starch-hydrolyzing alkalophile showing high intracellular isomaltose-hydrolyzing $\alpha$ glucosidase productivity was isolated from soil from a hot spring and identified as an alkalophilic Bacillus sp. strain. The purpose of this paper is to report some taxonomical characteristics of the isolated strain and the optimization of the isomaltose-hydrolyzing $\alpha$-glucosidase synthesis by this strain (F5). A few biochemical properties of the crude enzyme were also investigated for its further application in the starch processing industry.

\section{MATERIALS AND METHODS}

Materials. Maltose, isomaltose, panose and maltotriose were obtained from Hayashibara Biochemical Lab. Pullulan and $p$-nitrophenyl $\alpha$ D-glucopyranoside ( $p$-NPG) were purchased from Nakarai Chemicals Co. and Sigma Chemical Co., respectively. Soluble starch from Kanto Chemicals Co. was washed twice with deionized water followed by washing with acetone before use. Corn amylopectin and potato amylose were from Tokyo Kasei Kogyo Co. Potato. starch and corn steep liquor were supplied by Nihon Shokuhin Kako Co. Polypepton and yeast extract were obtained from Daigo Eiyo Co. and Difco Lab., respectively. The enzymatic assay kit for glucose determination, crystalline lysozyme and deoxyribonuclease were purchased from Fujisawa Yakuhin Kogyo Co., Seikagaku Kogyo Co. and Miles Lab., respectively. Adenosine $3^{\prime}, 5^{\prime}$-cyclic monophosphate (c-AMP), chloramphenicol, 2,4-dinitrophenol (2,4-DNP) and bovine serum albumin were from Sigma Chemical Co. Other chemicals used were of reagent grade and available commercially.

Isolation and identification of an isomaltosehydrolyzing $\alpha$-glucosidase-producing strain. A small amount of soil (about $0.1 \mathrm{~g}$ ), which was obtained at Mine hot spring (Shizuoka Pref., Japan), was suspended in $1 \mathrm{ml}$ of water. The suspension $(0.1 \mathrm{ml})$ was spread on agar plates $(15 \mathrm{ml}$ of isolation medium per plate, 9 $\mathrm{cm}$ in diameter) containing $1(\mathrm{w} / \mathrm{v}) \%$ soluble starch, $0.5 \%$ Polypepton, $0.5 \%$ yeast extract, $0.1 \% \mathrm{~K}_{2} \mathrm{HPO}_{4}, 0.02 \% \quad \mathrm{MgSO}_{4} \cdot 7 \mathrm{H}_{2} \mathrm{O}$ and $2 \%$ agar in water. The $\mathrm{pH}$ of the medium was adjusted to about 9.5 with $1 \% \mathrm{NaHCO}_{3}$, which has been sterilized separately at $121^{\circ} \mathrm{C}$ for 20 min. The plates were incubated at $37^{\circ} \mathrm{C}$ for $2-$ 3 days. Colonies appearing on the plates were inoculated into $10 \mathrm{ml}$ of the medium described above except that agar was omitted, in test tubes $(24 \mathrm{~mm} \mathrm{ID} \times 200 \mathrm{~mm} \mathrm{~L})$, followed by shaking-cultivation $(200 \mathrm{rpm})$ at $37^{\circ} \mathrm{C}$ for $48 \mathrm{hr}$. The isomaltose-hydrolyzing $\alpha$-glucosidase (isomaltase) activity in the culture broth was determined under the standard assay conditions. Taxonomical characteristics of the isolated strain were investigated according to the methods described in "Bergey's Manual of Systematic Bacteriology, Vol. 2"15) and "The Genus Bacillus." ${ }^{16)}$

Enzyme assay. Isomaltose-hydrolyzing $\alpha$ glucosidase activity was determined as follows: the reaction mixture, consisting of $3.6 \mathrm{mg}$ isomaltose in $0.45 \mathrm{ml}$ of $50 \mathrm{mM} \mathrm{Na}$ phosphate buffer ( $\mathrm{pH}$ 6.8) and $0.05 \mathrm{ml}$ of the enzyme solution, was incubated at $40^{\circ} \mathrm{C}$ for $10 \mathrm{~min}$. After terminating the reaction by heating for $3 \mathrm{~min}$ in a boiling water bath, glucose formed was determined enzymatically by the glucose oxidaseperoxidase method. ${ }^{17)}$ One unit of the enzyme activity is defined as the amount of enzyme that hydrolyzes $1 \mu \mathrm{mol}$ of isomaltose per min under the conditions described above.

Bacterial growth. Bacterial growth was determined spectrophotometrically at $660 \mathrm{~nm}$. The relationship between the cell mass weight and turbidity was as follows: an absorbance of 1.0 at $660 \mathrm{~nm}\left(A_{660}\right)$ is equivalent to $2.90 \mathrm{mg}$ wet cells per $\mathrm{ml}$ or to $0.496 \mathrm{mg}$ dry cells per $\mathrm{ml}$.

Protein concentration. Protein was determined by the method of Lowry et al. ${ }^{18)}$ with bovine serum albumin as a standard.

Base composition of chromosomal DNA. The guanine + cytosine content of chromosomal DNA, which was prepared according to the method of Saito and Miura, ${ }^{19)}$ was estimated from the thermal denaturation temperature as described by Marmur and Doty. ${ }^{20)}$

Preparation of the crude enzyme. The alkalophilic Bacillus sp. (F5) was cultured aerobically in $7 l$ of the isolation medium described above under the following conditions: 
temperature, $37^{\circ} \mathrm{C}$; aeration, $3.5 l$ per $\min$; and agitation, $250 \mathrm{rpm}$. After $24 \mathrm{hr}$ cultivation, the cells (184 g wet weight, $21.7 \mathrm{U} / \mathrm{g}$ wet cells) were harvested by centrifugation $(6000 \times g, 20$ $\min , 4^{\circ} \mathrm{C}$ ) and then washed twice with $20 \mathrm{~mm}$ $\mathrm{Na}$ phosphate buffer ( $\mathrm{pH} \mathrm{6.8)}$ containing 0.9 $\% \mathrm{NaCl}$. After the washed cells had been suspended again in $350 \mathrm{ml}$ of the same buffer containing $0.9 \% \mathrm{NaCl}$, the suspension was incubated at $40^{\circ} \mathrm{C}$ for $30 \mathrm{~min}$ with lysozyme $(1.75$ $\left.\times 10^{6} \mathrm{IU}\right)$ and deoxyribonuclease $\left(1.75 \times 10^{3} \mathrm{IU}\right)$. After removing the cell debris by centrifugation $\left(25,000 \times g, 30 \mathrm{~min}, 4^{\circ} \mathrm{C}\right)$, the clear supernatant was dialyzed overnight against water, followed by concentration with polyethylene glycol 6000 . As this preparation $(100 \mathrm{ml}, 36.0 \mathrm{U} / \mathrm{ml})$ did not show $\alpha$-amylase, ${ }^{21)}$ pullulanase ${ }^{22)}$ or isoamylase ${ }^{23)}$ activity, it was used as the enzyme source in this work.

\section{RESULTS}

\section{Characterization of the isolated strain}

Strain F5 grew at temperatures from 20 to $55^{\circ} \mathrm{C}$, with an optimum at $43-45^{\circ} \mathrm{C}$, in the isolation medium. The bacterium was strictly aerobic, motile, spore-forming, Gram-positive and rod-shaped cells with peritrichous flagella. The $\mathrm{pH}$ range for growth in the medium was 5.0 to 10.0 , the optimum being 9.5. The guanine plus cytosine content comprised 50.5 mol $\%$ of chromosomal DNA. Table 1 summarizes the morphological and cultural characteristics of the isolated strain. As the bacterium (F5) was identified as a strain of the genus Bacillus, on the basis the results described above, its taxonomical characteristics were compared with those of certain species of Bacillus. As shown in Table 2, the morphological characteristics of strain F5 resembled those of $B$. licheniformis, except for growth in nutrient broth under anaerobic conditions and acid formation from xylose, whereas its cultural and biochemical characteristics were similar to those of B. subtilis, except for propionate assimilation. On the other hand, the optimum $\mathrm{pH}$ for growth of strain F5 was entirely different from those of the comparable strains of Bacillus described above.
Table 1. Morphological, cultural and biochemical characteristics of strain No. F5.

$\begin{array}{ll}\text { 1. Morphological characteristics } \\ \text { Form } & \text { Rods } \\ \text { Size } & 0.5-0.7 \times 2.0-3.0 \mu \mathrm{m} \\ \text { Motility } & \text { Motile } \\ \text { Gram stain } & \text { Positive } \\ \text { Sporangia } & \text { Not swollen } \\ \text { Spores } & 0.5-0.7 \times 0.6-0.8 \mu \mathrm{m} ; \text { oval; } \\ & \text { central }\end{array}$

2. Cultural characteristics

Nutrient broth

Nutrient agar slant

Glucose-nutrient broth

Glucose-nutrient agar slant

Glucose-nitrate agar slant

Glucose-asparagine agar slant

Anaerobic growth in glucose broth

Anaerobic production of gas from nitrate -

Alkaline I-medium* ++

Alkaline II-medium** $\quad++$

Alkaline I-medium* containing $5 \% \mathrm{NaCl}++$

3. Biochemical characteristics

Hydrolysis of gelatin and casein Positive

Hydrolysis of starch _. Positive

Utilization of citrate Utilized

Utilization of ammonium salts Utilized

Reduction of nitrate to nitrate Reduced

Voges-Proskauer test Positive

4. $\mathrm{pH}$ and temperature

$\mathrm{pH}$ for growth in II-medium $* *\left(37^{\circ} \mathrm{C}\right)$

pH 5.0 to 10.0

Temp. for growth in II-medium** (pH 9.3)

20 to $55^{\circ} \mathrm{C}$

-, indicates no growth; + , normal growth; ++ , abundant growth. *: $1 \%$ glucose, $0.5 \%$ Polypepton, $0.5 \%$ yeast extract, $0.1 \% \mathrm{~K}_{2} \mathrm{HPO}_{4}, 0.02$ $\% \mathrm{MgSO}_{4} \cdot 7 \mathrm{H}_{2} \mathrm{O}$ and $1 \% \mathrm{NaHCO}_{3}$. "**: $1 \%$ soluble starch, $0.5 \%$ Polypepton, $0.5 \%$ yeast extract, $0.1 \% \mathrm{~K}_{2} \mathrm{HPO}_{4}, \quad 0.02 \% \mathrm{MgSO}_{4} \cdot 7 \mathrm{H}_{2} \mathrm{O}$ and $1 \% \mathrm{NaHCO}_{3}$.

Some cultural conditions on the enzyme production

As the isolated strain grew well under alkalophilic conditions, the $\mathrm{pH}$ of the medium was kept on the alkaline side. As shown in Fig. 1, 
Table 2. Comparison of some characteristics of Bacillus sp.

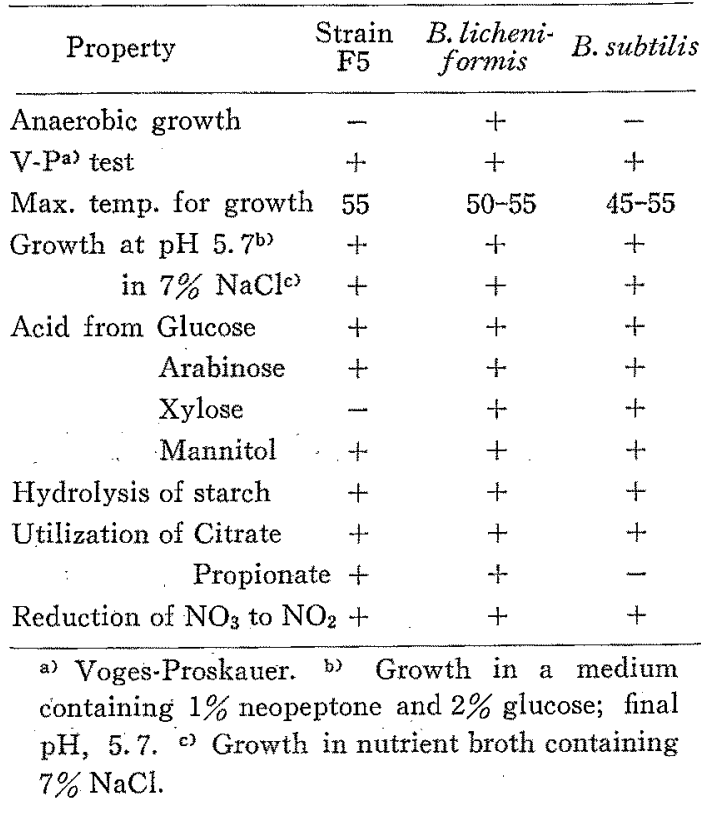

the enzyme was synthesized when the bacterium was grown under neutral to alkaline $\mathrm{pH}$ conditions, the most preferable initial $\mathrm{pH}$ for the culture medium being 9.0-9.5.

Various carbohydrates (1\%) were compared as carbon sources for the enzyme production using the isolation medium with starch omitted. The enzyme activity in the culture broth after $24 \mathrm{hr}$ cultivation at $37^{\circ} \mathrm{C}$ was determined by the standard assay method. As shown in Table 3, although the bacterium grew well in all media, including that with no added carbon source, maltose, soluble starch and potato starch were better carbon sources for the enzyme production. When strain F5 was grown in the media containing monosaccharides (glucose, fructose and galactose), polyols (sorbitol, mannitol and glycerol) and organic acids ( $\delta$-gluconolacton and D-glucuronic acid), a trace amount of the enzyme was formed (data only shown partly). To determine whether or not the enzyme synthesis was induced by these carbohydrates, bacterial cells, which had been harvested by contrifugation $\left(6000 \times \mathrm{g}, 20 \mathrm{~min}, 4^{\circ} \mathrm{C}\right)$ after $20 \mathrm{hr}$ cultivation at $37^{\circ} \mathrm{C}$ in the isolation medium containing $1 \%$ glycerol instead of soluble starch,

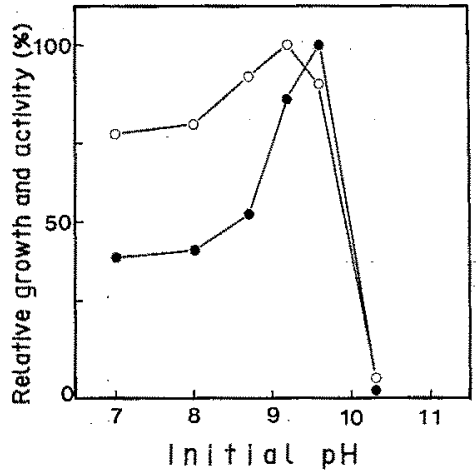

Fig. 1. Effects of $\mathrm{pH}$ on growth and isomaltosehydrolyzing $\alpha$-glucosidase formation.

The isolated strain was cultured aerobically at $37^{\circ} \mathrm{C}$ in the liquid isolation medium described in the text except supplemented with agar and $\mathrm{Na}$ $\mathrm{HCO}_{3}$. The medium $\mathrm{pH}$ was adjusted with $\mathrm{Na}$ $\mathrm{HCO}_{3}(0.25,0.5$ and $1.0 \%)$ and $\mathrm{Na}_{2} \mathrm{CO}_{3}(0.5$ and $1.0 \%$ ). After 2 days cultivation, the bacterial growth and enzyme activity were determined by the standard methods. A hundred \% bacterial growth or enzyme activity corresponds to $5.32 \mathrm{mg}$ dry cells or $0.74 \mathrm{U} / \mathrm{ml}$.

Symbols: bacterial growth (O) and enzyme activity (•).

Table 3. Effects of carbon sources on isomaltosehydrolyzing $\alpha$-glucosidase formation.

\begin{tabular}{lcc}
\hline Carbon source & Growth & Activity $(\mathrm{mU} / \mathrm{ml})$ \\
\hline None & + & 0 \\
Glycerol & + & 0 \\
Glucose & ++ & 0 \\
Multose & ++ & 510 \\
Saccharose & + & 12 \\
Lactose & + & 0 \\
Dextran & + & 6 \\
Potato starch & ++ & 780 \\
Soluble starch & ++ & 690 \\
\hline
\end{tabular}

+ , indicates normal growth; ++ , abundant growth. The isolated strain was cultured at $37^{\circ} \mathrm{C}$ in the liquid isolation medium described in the text supplemented with each carbon sources other than soluble starch. After 24 hr cultivation, the enzyme activity was determined by the standard method.

were inoculated again into medium containing $1 \%$ of glucose, maltose or soluble starch, followed by shaking-cultivation for $5 \mathrm{hr}$. As shown 
Table 4. Induction of isomaltose-hydrolyzing $\alpha$-glucosidase formation by maltose and starch.

\begin{tabular}{llrr}
\hline \multirow{2}{*}{ Addition } & \multicolumn{3}{c}{ Activity $(\mathrm{mU} / \mathrm{ml})$} \\
\cline { 2 - 4 } & $\begin{array}{l}\text { reinocu- } \\
\text { lation }\end{array}$ & after $3 \mathrm{hr}$ & after $5 \mathrm{hr}$ \\
\hline Glycerol & $0(1.52)^{*}$ & $0(2.40)$ & $0(2.14)$ \\
Glucose & $0(1.21)$ & $0(2.56)$ & $0(3.19)$ \\
Maltose & $0(1.44)$ & $297(2.14)$ & $551(2.54)$ \\
Soluble starch & $0(1.61)$ & $0(1.75)$ & $46(1.88)$
\end{tabular}

*: Values in parentheses represent the bacterial growth of the culture (mg dry cell $/ \mathrm{mI}$ broth). The cells, which were cultured aerobically at $37^{\circ} \mathrm{C}$ for $15 \mathrm{hr}$ in the liquid isolation medium supplemented with $1 \%$ glycerol instead of soluble starch, were harvested by centrifugation aceptic ally and then reinoculated to fresh liquid isolation medium.

Table 5. Effects of nitrogen sources on isomaltosehydrolyzing $\alpha$-glucosidase formation.

\begin{tabular}{lcc}
\hline Nitrogen source & \multicolumn{1}{c}{ Activity $(\mathrm{mU} / \mathrm{ml})$} \\
\hline Defatted soybean powder & $5 \%$ & 1410 \\
Rice bran & $5 \%$ & 790 \\
Wheat bran & $5 \%$ & 680 \\
Corn steep liquor & $5 \%$ & 840 \\
Meat extract & $1 \%$ & 440 \\
Casein & $1 \%$ & 260 \\
Casamino acid & $1 \%$ & 430 \\
Bacto peptone & $1 \%$ & 340 \\
Polypepton & $1 \%$ & 920 \\
\hline
\end{tabular}

Cultures were aerobically grown at $37^{\circ} \mathrm{C}$ in the liquid isolation medium supplemented with each nitrogen sources instead of Polypepton. After 24 hr cultivation, the enzyme activity was determined by the standard method.

in Table 4, synthesis of the enzyme was induced by all these carbohydrates except glucose.

Table 5 shows the effects on the enzyme production of various organic nitrogen sources ( 1 or $5 \%$ ) instead of Polypepton in the isolation medium. Among the organic nitrogen sources tested, defatted soybean powder was the most suitable nutrient. But Polypepton was used as a nutrient source to investigate the relationship between bacterial growth and enzyme synthesis in a growing culture. The enzyme was not

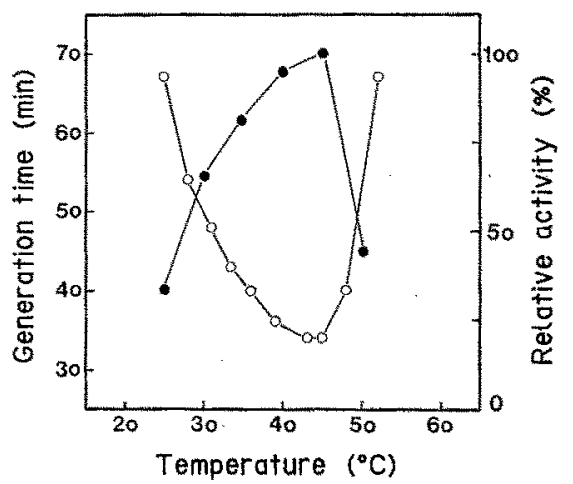

Fig. 2. Effects of temperature on growth and isomaltose-hydrolyzing $\alpha$-glucosidase formation.

Cultures were aerobically grown in Monod L. tubes containing $10 \mathrm{ml}$ of the liquid isolation medium in a temperature gradient incubator. A hundred $\%$ bacterial growth or enzyme activity corresponds to $3.63 \mathrm{mg}$ dry cells or $1.28 \mathrm{U} / \mathrm{ml}$.

Symbols: generation time (O) and enzyme activity

formed with inorganic nitrogen compounds (1\% each) such as $\left(\mathrm{NH}_{4}\right)_{2} \mathrm{SO}_{4}, \mathrm{NH}_{4} \mathrm{Cl}, \mathrm{NH}_{4} \mathrm{NO}_{3}$, $\left(\mathrm{NH}_{4}\right)_{2} \mathrm{HPO}_{4},\left(\mathrm{NH}_{4}\right)_{2} \mathrm{CO}_{3}$, including ammonium acetate, ammonium citrate and urea (data not shown).

Effects of temperature on bacterial growth and isomaltose-hydrolyzing $\alpha$-glucosidase formation

The effects of temperature on growth and enzyme production by the alkalophilic Bacillus sp. (F5) were examined in a temperature gradient incubator. As shown in Fig. 2, the optimum temperature for bacterial growth was $43-45^{\circ} \mathrm{C}$ and that for enzyme synthesis was 45 ${ }^{\circ} \mathrm{C}$. The generation times of this bacterium were 34 and $40 \mathrm{~min}$ on cultivation at 45 and $36^{\circ} \mathrm{C}$, respectively.

Time courses of isomaltose-hydrolyzing $\alpha$-glucosidase production in the absence and presence of inhibitors

The relationship of bacterial growth and enzyme formation was examined when strain F5 was cultured aerobically for a long time in the isolation medium. As shown in Fig. 3, logarithmic growth continued for $20 \mathrm{hr}$ after an about $10 \mathrm{hr}$ lag time. 


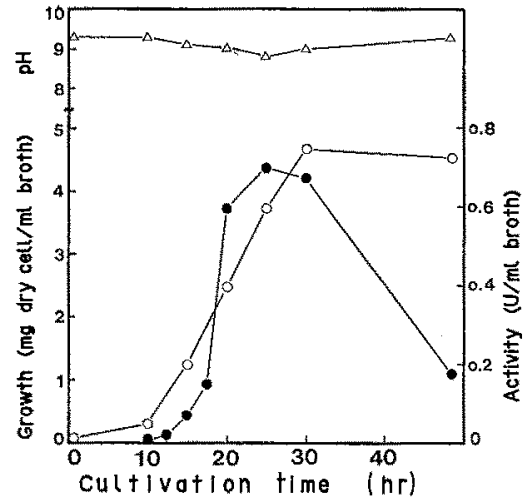

Fig. 3. Formation of isomaltose-hydrolyzing $\alpha$ glucosidase in a growing culture of alkalophilic Bacillus sp. F5.

Cultures were aerobically grown in $7 l$ of the liquid isolation medium in a $10 l$ jar-fermenter at $37^{\circ} \mathrm{C}, 250 \mathrm{rpm}$ and $3.5 l$ per min. The cells which were inoculated had been precultured at $37^{\circ} \mathrm{C}$ for $15 \mathrm{hr}$ with rotatory shaking (200 rpm, $70 \mathrm{~mm}$ amplitude) in $500 \mathrm{ml}$ Erlenmeyer flasks containing $100 \mathrm{ml}$ of the same medium.

Symbols: bacterial growth (O), enzyme activity ( $)$ and $\mathrm{pH}$ of the culture broth $(\Delta)$.

During the stationary growth phase, the cell concentration remained almost constant for about $15 \mathrm{hr}$ and then gradually decreased during the remainder of the experimental period. The formation of intracellular isomaltose-hydrolyzing $\alpha$-glucosidase increased gradually with bacterial growth, the maximum accumulation being attained within $30 \mathrm{hr}$. Then, the enzyme activity decreased gradually during the stationary growth phase. Figure 4 shows the effects of aeration, respiration and protein synthesis on the enzyme production. The addition of 2,4-DNP or chloramphenicol to a culture of strain F5, which was actively synthesizing isomaltose-hydrolyzing $\alpha$-glucosidase, caused gradual cessation of further enzyme synthesis. The enzyme synthesis was also weakly suppressed when aeration was stopped.

Effects of $p H$ and temperature on the enzyme activity and stability

The effects of $\mathrm{pH}$ and temperature on the activity of the crude enzyme are shown in Fig. 5, $\mathrm{A}$ and $\mathrm{B}$. The enzyme was most active at $\mathrm{pH} 6.0-6.5$ and $45^{\circ} \mathrm{C}$. The effects of $\mathrm{pH}$ and

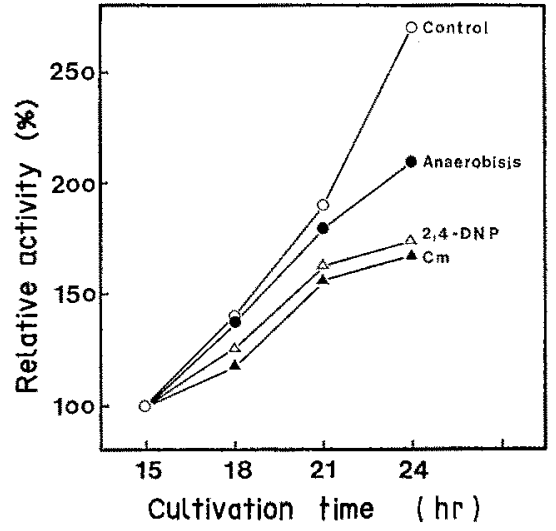

Fig. 4. Inhibition of isomaltose-hydrolyzing $\alpha$ glucosidase synthesis in growing cultures by inhibitors or on discontinuance of aeration.

Cultures were aerobically grown with rotatory shaking (200 rpm, $70 \mathrm{~mm}$ amplitude) in $500 \mathrm{ml}$ Erlenmeyer flasks containing $100 \mathrm{ml}$ of the liquid isolation medium at $37^{\circ} \mathrm{C}$. After $15 \mathrm{hr}$ cultivation, the inhibitors were added or aeration was stopped.

Symbols: control $(\mathrm{O})$, discontinuance of aeration (๑), $5 \mathrm{mM}$ 2,4-dinitrophenol (2,4-DNP) (A) and $50 \mu \mathrm{g} / \mathrm{ml}$ chloramphenicol (Cm) (A).

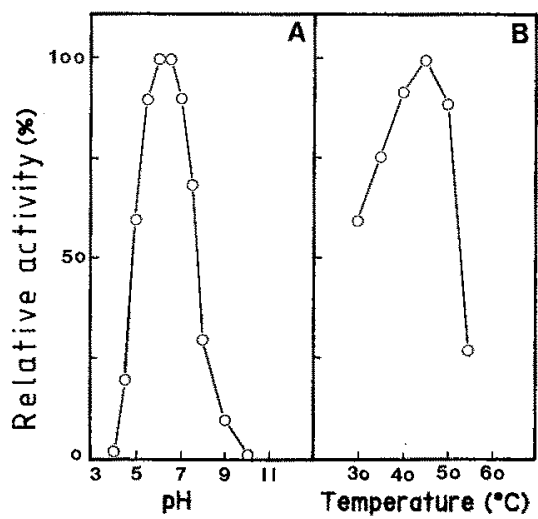

Fig. 5. Effects of $\mathrm{pH}$ and temperature on the activity.

The enzyme activity was determined by the standard assay method at various $\mathrm{pHs}$ and temperatures. Buffers used: $50 \mathrm{mM}$ citrate-sodium citrate ( $\mathrm{pH}$ 4.0-6.0), $50 \mathrm{mM} \mathrm{Na}_{2} \mathrm{HPO}_{4} \cdot \mathrm{NaH}_{2} \mathrm{PO}_{4}$ (pH 6.0-8.0), glycine- $\mathrm{NaCl}-\mathrm{NaOH}(8.0-10.0)$ and $\mathrm{Na}_{2} \mathrm{HPO}_{4} \cdot \mathrm{NaOH}$ (pH 11.0-12.0). 


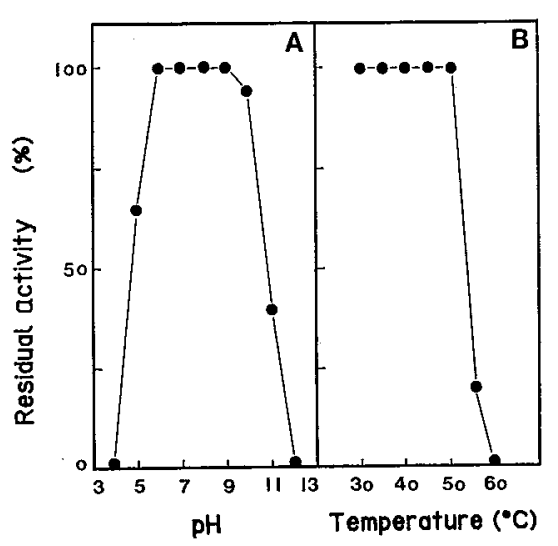

Fig. 6. Effects of $\mathrm{pH}$ and temperature on the stability.

The remaining activities after incubation at various $\mathrm{pHs}$ and temperatures for $10 \mathrm{~min}$ at 40 ${ }^{\circ} \mathrm{C}$ (A) and $\mathrm{pH} 7.0(\mathrm{~B})$, respectively, were determined by the standard assay method. The buffers used were the same as described in Fig. 5.

temperature on the stability of the crude enzyme are shown in Fig. 6, $\mathrm{A}$ and $\mathrm{B}$. The enzyme was most stable at $\mathrm{pH} 5.0-9.0$ and up to $50^{\circ} \mathrm{C}$.

\section{DISCUSSION}

Although many reports have appeared on the characterization of microbial $\alpha$-glucosidases, ${ }^{6 \sim 14)}$ few have appeared on the conditions influencing the production and characterization of bacterial oligo-1, 6-glucosidases other than $p$ NPG-hydrolyzing $\alpha$-glucosidases of $B$.thermoglucosidius ${ }^{13)}$ and B.cereus, ${ }^{14)}$ which catalyze the hydrolysis of isomaltose and a series of isomaltooligosaccharides slightly.

The present results demonstrated the synthesis of an isomaltose-hydrolyzing $\alpha$-glucosidase by a starch-degrading alkalophilic soil bacterium, which has been tentatively identified as a Bacillus strain. The synthesis of the isomaltosehydrolyzing $\alpha$-glucosidase by this bacterium was significantly stimulated, through induction, in medium containing maltose or starch as a carbon source. These features were also observed for the enzyme production by the other strains mentioned above.

The generation time of the isolate was longer than those of neutraliphilic Bacillus sp. ${ }^{24)}$ such as B. subtilis and B. licheniformis, but it represented a normal value for some strains of alkalophilic Bacillus sp. ${ }^{25)}$

The addition of an inhibitor of protein synthesis to a culture of the isolated strain, which was actively synthesizing isomaltose-hydrolyzing $\alpha$-glucosidase, caused gradual cessation of further enzyme synthesis. The enzyme synthesis was also weakly suppressed on the inhibition of respiration with 2,4-dinitrophenol (2,4-DNP) and on the termination of the shaking cultivation. This may be due to an insufficient supply of ATP for the enzyme synthesis. These results suggest that the appearance of isomaltose-hydrolyzing $\alpha$-glucosidase in cells during the logarithmic phase of growth involves de novo protein synthesis, although the enzyme production continued for a certain time after the termination of respiration or protein synthesis. Generally, cAMP acts as a releaser of catabolite repression in the production of extracellular carbohydrases. ${ }^{26)}$ The enzyme production was strongly suppressed in the presence of glycerol and glucose as carbon sources, however, no stimulatory effect on the enzyme synthesis was observed when c-AMP was added, at various bacterial growth phases, to the culture medium containing soluble starch as a carbon source (data not shown). As noted elsewhere, ${ }^{27)}$ the inner $\mathrm{pH}$ of cells of alkalophilic microorganisms is nearly neutral. Furthermore, it has been found that the optimum $\mathrm{pHs}$ for the actions of almost all cell-associated enzymes in alkalophilic microorganisms are also near neutrality. ${ }^{25,28,29)}$ In the present work, the optimum $\mathrm{pH}$ for the intracellular isomaltosehydrolyzing $\alpha$-glucosidase of strain F5 was also found to be near neutrality. Purification of the enzyme is now in progress for further investigation of its properties and its application in the starch processing industry.

\section{REFERENCES}

1) W. M. FogARTY and C.T. KeLLY: in Economic Microbiology, Vol.5, Microbial Enzymes and Bioconversions, A. H. Rose, ed., Academic Press, New York, p. 115-170 (1980).

2) B. E. NORMAN: Stärke, 34, 340-346 (1982).

3) E. J. HEHRE, G. OKADA and D. S. GENGHOF: Arch. Biochem. Biophys., 135, 75-89 (1969).

4) V.BESCHKOV, A. MARC and J.M. ENGASSER: 
Biotech. Bioeng., 26, 22-26 (1984).

5) S. ADACHI, Y. UEDA and K. HASHIMOTO: Biotechnol. Bioeng., 26, 121-127 (1984).

6) C. T. Kelly and W.M. Fogarty: Process Biochem., 18(3), 2-8 (1983).

7) Y. YAMASAKI and Y. SuZuki: Agric. Biol. Chem., 38, 443-454 (1974).

8) L.-H. WANG and P.A. Hartman: Appl. Environ. Microbiol., 31, 108-118 (1976).

9) C. T. KELLY, F. O'REILLY and W. M. FogaRTY: FEMS Microbiol. Lett., 20, 55-59 (1983).

10) L.-H. LI and K.-Y.CHAN: Appl. Environ. Microbiol., 246, 1380-1387 (1983).

11) I. Igaue, S. WATANABE, T. OdA and K. KoYAMADA: Nippon Nógeikagaku Kaishi: 57, 985-994. (1983).

12) S. TABATA, T. IDE, Y. UMEMURA and K. TORII: Biochim. Biophys. Acta, 797, 231-238 (1984).

13) Y.SuZUKI, T. YukI, T. KISHIGAMI and S. ABE: Biochim. Biophys. Acta, 445, 386-397 (1976).

14) Y.Suzuki, R. AokI and H. HAYASHI: Biochim. Biophys. Acta, 704, 476-483 (1982).

15) N.R. KRIEG and J.G. HolT: Bergey's Manual of Systematic Bacteriology, Vol.2, Williams and Wilkins, Baltimore, p. 1104-1139 (1986).

16) R.E.GoRdon, W.C. HAYNES and C. H.-N. PANG: The Genus Bacillus, Agricultural Research Service, U.S. Dept. of Agriculture, Washington, D. C., p. 34-41, p. 248-252 (1973).

17) P. Trinder: Ann. Clin. Biochem., 6, 24-28 (1969).

18) O. H. LOWRY, N. J. Rosebrough, A. L. FARR and R. J. RANDALL: J.Biol.Chem., 193, 265-275 (1951).

19) H. Sarto and K. Miura: Biochim. Biophys. Acta, 72, 619-629 (1963).

20) J. MARMUR and P. Doty: J.Mol. Biol., 5, 109118 (1962).

21) H. FUWA: J. Biochem., 41, 583-603 (1954).

22) K. WALlenfels, H. BENDER and J. R. RACHED: Biochem. Biophys. Res. Commun., 22, 254-261 (1966).

23) K. YOKOBAYASHI, A. MISAKI and T. HARADA:
Biochim. Biophys. Acta, 212, 458-469 (1970).

24) K. Tomita: Bioindustry, 3, 5-13 (1986).

25) T. AKINo, N. NAKAMURA and K. Horikoshi: Appl. Microbiol. Biotechnol., 26, 323-327 (1987).

26) N. Saito: Arch. Biochem. Biophys., 155, 290-298 (1973).

27) K. Horikoshi and T. AKIBA: Alkalophilic Microorganisms, Japan Scientific Societies Press, Tokyo (1982).

28) T. AKIBA and K. Horikoshi: Agric. Biol. Chem., 40, 1851-1856 (1976).

29) Y. IKURA and K. Horikoshi: Agric. Biol. Chem., 43, 1359-1360 (1979).

好アルカリ性細菌 Bacillus sp. 飞よる イソマルトース加水分解型 $\alpha$ グルコ シダーゼの生産

山本幹男，掘越弘毅

理化学研究所微生物生態学研究室 （351-01 和光甫広沢 2-1）

Bacillus 属に属し，菌体内にイソマルトース加水分解 型 $\alpha$ グルコシダーゼを生産する好アルカリ性細菌を温 泉土壤加ら分離した. 本菌 (strain No.F5) は, $\mathrm{pH}$

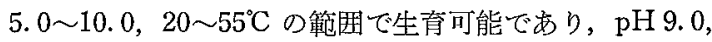
$45^{\circ} \mathrm{C}$ 付近でもっともよく生育した.

イソマルトース加水分解型 $\alpha$ ーグルコシダーゼは本菌 を $1 \%$ 可溶性潵粉またはマルトース，5\%脱脂大豆粉， $0.1 \% \mathrm{~K}_{2} \mathrm{HPO}_{4}, 0.02 \% \mathrm{MgSO}_{4} \cdot 7 \mathrm{H}_{2} \mathrm{O}$ および $1 \% \mathrm{Na}$ $\mathrm{HCO}_{3}$ を含む培地を用いて $45^{\circ} \mathrm{C}$ で据気的に培養するこ

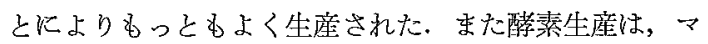
ルトースや可溶性澱粉により強く誘導された。

粗酳素の至適 $\mathrm{pH}$ は $6.0 \sim 6.5$, 至適温度は $45^{\circ} \mathrm{C}$ で あった。 